\title{
Entrepreneurial Intentions Among Undergraduate Students: A case study of Adeleke Univerity Ede, Osun State, Nigeria
}

\author{
Adeoye, 0.0. \\ Department of Accounting, \\ Adeleke University \\ Ede, Osun State, Nigeria. \\ Email:muyiwa.adeoye@adelekeuniversity.edu.ng \\ https://orcid.org/0000-0003-4935-4259
}

\begin{abstract}
The study assessed the student's career choice and entrepreneurial intentions of Adeleke University Ede, Nigeria. Specifically, it evaluated undergraduate students entrepreneurial intentions immediately after graduation; examined students characteristics with entrepreneurial activities and choices. This study was fashioned based on a model developed by Ajzen. The survey design was adopted, and self-administered questionnaires were distributed to a total of 250 students randomly selected. With the aid of SPSS, the collected data was analyzed using descriptive and inferential statistics. Results have revealed that the various school entrepreneurial programmes attendance has induced heightened interest in entrepreneurial intention only after school but not in the school. The findings also showed a positive relationship between gender, age, career choice, parents occupation, and entrepreneurial intentions among undergraduate students. The study recommended that universities focus their attention on attracting students towards entrepreneurial programmes as students who attended entrepreneurial courses/training showed significantly higher entrepreneurial intentions. The school and parents should equally provide moral and financial encouragement to motivate students into entrepreneurial development.
\end{abstract}

Keywords: Entrepreneur, intention, education, behaviour, students

Proceedings ReferenceFormat

Adeoye, O.O.. (2021): Entrepreneurial Intentions Among Undergraduate Students: A case study of Adeleke Univerity Ede, Osun State, Nigeria. Proceedings of the 27th iSTEAMS Multidisciplinary Innovations \& Technology Transfer (MINTT) Conference.Academic City University College, Accra, Ghana. June, 2021. Pp 95- 110 www.isteams.net/ghana2021. DOI - https://doi.org/ 10.22624/AIMS/iSTEAMS-2021/V27P10

\section{INTRODUCTION}

Entrepreneurship has been given serious attention in recent years, mainly because of its potentials to enhance economic growth and promote development by creating jobs (Urbano \& Aparicio, 2015). The research in this direction is considered indispensable to the growth and development of a nation. To this end, every nation, especially the developing ones, have been encouraged to make entrepreneurship enticing and attractive to their teeming youths for engagement. The country's future development is anchored on the level of nascent entrepreneurs that the government has built and develops (Nafukho, Helen \& Muyia, 2010). Budding entrepreneurs will help in forming a healthy economy. It corroborates Dickson, Solomon, and Mark Weaver (2008) and Siyanbola et al. (2012) that entrepreneurship development is vital to economic sustainability. 


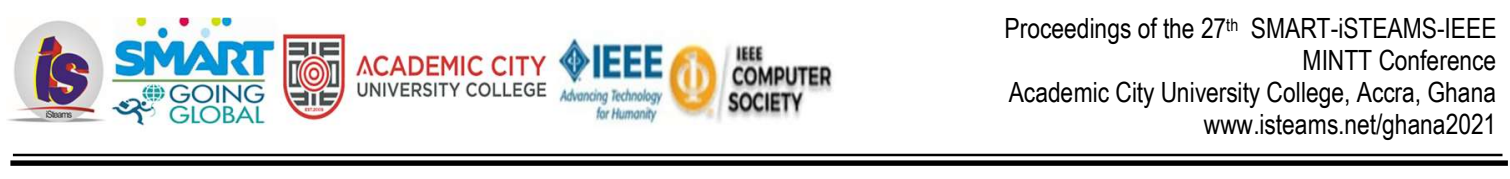

Therefore, a deliberate and conscious strategy is required to cultivate entrepreneurship in an economy. More so, the current global economic challenges and rapid technological advances have mounted pressure on the tertiary institution to produce job-creating graduates since the certificate is no longer a guarantee for employment (Ntemngweh, 2016). The government's deliberate strategy justifies entrepreneurship courses in most tertiary institutions' curricula across the globe. It has been documented that entrepreneurship education is an essential measure for facilitating and promoting students interest in entrepreneurship in the university system (NUC, 2006; Adelowo et al., 2015). Despite introducing entrepreneurship courses into the tertiary education curriculum for the past few decades in Nigeria, its unemployment rate still worsened. However, there is an upsurge in entrepreneurial interest among the students (Olofinyehun et al., 2017).

Therefore entrepreneurship education probably triggers interest in the students, but with failing institutions and poor business climate, it becomes difficult to transit to entrepreneurial actions. The cycle of unemployment continues as there is a slow pace of business creation, even with the evolution of high-tech business opportunities. Instilling the spirit of entrepreneurship among students is an essential part of every university's effort to contribute to the country's growth. Therefore, it is necessary to assess this effort by examining the students present and future intentions concerning entrepreneurship development.

As crucial as entrepreneurship studies are, there is still a significant gap in knowledge about the extent of student involvement in entrepreneurship, primarily by examining the student's intention to shape entrepreneurship given the amount of entrepreneurial education embedded in Nigerian university curricula.

\subsection{Statement of Problem}

The rising cases of youth restiveness and unemployment have been a source of concern in the country. The poor state of the economy is attributed to the low situation for entrepreneurship occasioned by its inability to mobilize her enterprising young entrepreneurs in Nigeria to entrepreneurial activities (Adamu, 2017). As observed by Agbim, Oriarewo, and Owocho (2012), the Nigerian educational system, especially the universities, have not been able to draw to minds of an appreciable number of youths which the country is blessed with into entrepreneurship. Copious studies have been conducted on entrepreneurship development among youth. Such investigations highlight career choice intentions among university students (Sieger \& Moen, 2015); the antecedents to entrepreneurial intentions by Bergmann, Hundt, and Sternberg (2016). However, very few studies exist on university students entrepreneurial intentions in developing countries, including Nigeria (Lima, Lopes, Nassif, \& Da Silva, 2015). Hence, this study investigated the level of entrepreneurial intention among undergraduate students.

\subsection{Research Objectives}

The broad objective is to assess the student's career choice and entrepreneurial intentions of Adeleke University Ede, Nigeria. The specific objectives are to:

1. evaluate entrepreneurial intentions of undergraduate students immediately after graduation.

2. examine the characteristics of students with entrepreneurial activities and intentions among undergraduate students in the study area;

3. assess the obstacles to entrepreneurship development and start-up activities among undergraduate students 


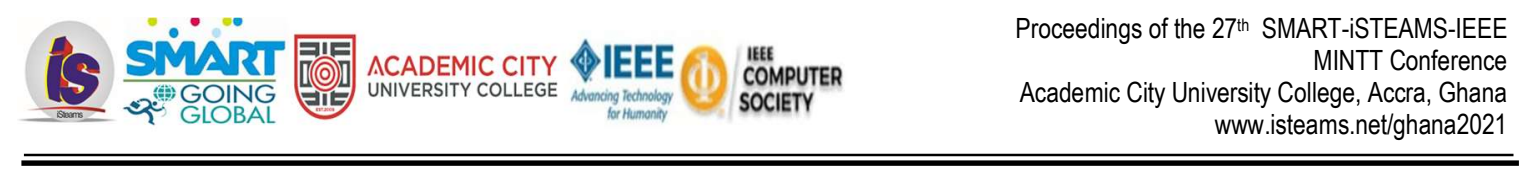

\subsection{Statement of Hypothesis}

The following hypethesis guides the research

$\mathrm{HO}_{1}$ : Students socio-cultural characteristics have no relationship with the present entrepreneurial choice and intentions among undergraduate students

$\mathrm{HO}_{2}$ : Students academic characteristics have no relationship with the entrepreneurial choice and intentions among undergraduate students

\section{LITERATURE REVIEW}

\subsection{Entrepreneurship}

Entrepreneurship has attracted copious definitions in the literature, primarily due to its importance to socioeconomic growth. Wickham (2001) opines that entrepreneurship entails the essential activities that a person committedly engages in and how people carried out these activities to earn his/her socio-economic wellbeing. It involves a set of activities that requires committed effort to actualize. The entrepreneurial intention reflects the self-acknowledged belief of an individual's mind, which can give him or her the opportunity to set up a business with sincerity and dedication for a plan at a point in time (Thompson, 2009). In the same vein, (Dohse and Walte (2010) viewed entrepreneurial intention as the formation and willingness of a person to be involved in entrepreneurial activities or be self-reliant. It requires determination, braveries and conviction for an individual to form a new business. Ismail, Khalid, Othman, Jusoff, Rahman, Kassim and Zain, (2009) stated that an individual might have the potential to be an entrepreneur or possess positive possibilities to lack the intention and also the conversion of entrepreneurial activities.

Numerous issues were noted as affecting the formation of entrepreneurship in the literature. Scholars have researched and built several approaches to identify factors that could affect the intention of individuals to shape their company, such as personality traits (Owoseni 2014), attitudes, values, beliefs (Gasse \& Tremblay 2011), demographic barriers such as gender, age (Deh, assume \& Agyemang 2013) and the level of student studies (Bhandari, 2013)Literature shows that intention could be viewed as a crucial component when creating a new venture (Bates et al., 2013). An individual who has the prospect of forming a business and has the competence to get involved in entrepreneurship and lack entrepreneurial intention might not like to be involved in business or any risk of such nature. It is essential to have entrepreneurial intentions, which will inspire the formation of entrepreneurial activities. Therefore, investigating the individual's intention towards self-employment will offer researchers a meaningful inspiration to apprehend and forecast entrepreneurial stages and entrepreneurship activities that can successfully set out the importance of entrepreneurial intention (Ismail et al., 2009).

\subsection{Empirical Review}

Several studies have documented varying reports on the determinants of entrepreneurial intention among undergraduate and graduate students. For instance, the strength of the method in different cultural environments involving the Scandinavian countries and the US was studied by Autio et al. (2001) and established that subjective norm, as reflected in the seeming general suitability of entrepreneurship as a career choice, influences entrepreneurial intention. Also, Lüthje and Franke (2003) focused their investigation on MIT engineering students entrepreneurial intention. Forming entrepreneurship is influenced by prominent factors that include personality traits, belief, perceived barriers and support elements. 


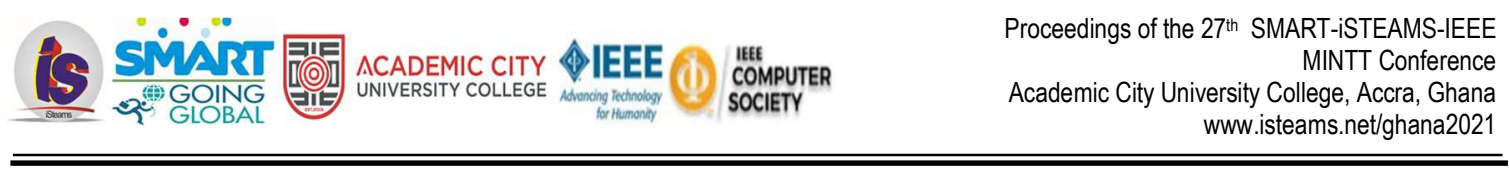

Similarly, Gurel, Altinay and Daniele, (2010) surveyed the tourism students entrepreneurship intention in both the UK and Turkey. They found a statistically significant relationship between innovation, propensity to take risks, entrepreneurial family and entrepreneurial intention. The determinants of entrepreneurial interest in Singapore were studied by Wang and Wong (2004) and discovered that inadequate knowledge and perceived risk are essential pointers to entrepreneurial intention.

Gerry, Marques and Nogueira (2008) adopted multivariate statistical techniques to evaluate graduates' entrepreneurial potential at a Portuguese university. Their study indicated that gender, risk factors and academic training are prominent factors that underline entrepreneurial intention in the Portuguese University. Other studies such as Shariff and Saud (2009), Zain, Akram and Ghani (2010), Sandhu, Sidique and Riaz (2011), Keat, Selvarajah and Meyer (2011) investigated the determinants of entrepreneurial intention among Malaysian university students. They found various education-based, demographic and business background variables as statistically significant.

Boissin et al. (2009) established that the intention to start up a business was more robust in the US than in France and revealed significant beliefs among the new business owners. In their review of Austrian University students, Turker and SonmezSelcuk (2009) showed that educational and structural support influenced students entrepreneurial intention at a Turkish university. Zampetakis et al. (2009) focused on the emotional intelligence, entrepreneurial attitudes and intentions of Greek students. The findings of their study offered strong support for the idea that students' imagination and proactivity mitigate the positive effect of emotional intelligence on entrepreneurship attitudes. Thus, these varying submissions indicate a mixed report in the literature on entrepreneurial intention and its determinants.

\subsection{Theoretical Framework: Theory of Planned behaviour and Career Choice Intention}

This study is anchored on Planned Behaviour's theory, propounded by Fishbein and Aizen (1975) and promoted in Ajzen and Fishbein (1980). This theory forecasts and describes human behaviour in a solid framework, which involves estimating people's behavioural disposition towards a particular act. The Theory of Plan Behaviour explains the motivators of behaviour, although the mere intention was insufficient to forecast behaviour. It specifies that people are expected to change their intention into action if there is an acceptable degree of real control over the behaviour (Ajzen \& Fishbein, 2000). Thus, the intention is presumed to be the direct precursor of behaviour, controlling the behaviour in a controlled means (Ajzen, 1991).

Entrepreneurial behaviour is not easily determined or established since it is difficult to perceive and includes unpredictable time lags (Krueger \& Brazeal, 1994). According to Ajzen (2002), human behaviour is guided by behavioural, normative, and control beliefs or perceptions. Thus, as propounded by Ajzen (1991), the theory of planned behaviour has appeared as a critical theoretical framework that describes intentions as the most real determinant of actual behaviour. It has become the fundamental element of explaining behaviour not only in employment but also in academic preferences. As described by demographic variables such as age, gender, academic performance, and field of study, students' career choice intentions prescribe what students propose to do during or after their studies and what they intend to do both short-term and long-term in their career plan. 


\section{METHODOLOGY}

A descriptive survey research design was used in this report. All final-year undergraduate students at Adeleke University in Ede were included in the report. In this research, since the entrepreneurship curriculum and activities are well incorporated into the academic programs, the University was chosen to represent the community. The total population of final year students at the time of conducting this study is 865 . Specifically, the study's focus was on the graduating students who have offered and participated in entrepreneurial studies right from their inception in the University, and this totals 268. Using the simple random technique, 250 students were selected as a sample size for the study. Data were collected via a self-administered questionnaire. The questionnaire made use of data generated in the Global University Entrepreneurial Spirit Students Survey (GUESS), an international research project that was organized and conducted by the UGC-HSG Institute of the University of St. Gallen (Switzerland). The data generated were analyzed using descriptive, inferential statistics.

\section{FINDINGS}

The respondents' socio-demographic characteristics show that the sample included respondents from the female category as $58 \%$ and $42 \%$ males. The mean age was 27 years old. Responses in faculties' composition included Faculty of Business and Social Science 33\%, Faculty of Science 22\%, faculty of Engineering 22\%, Faculty of Basic Medical Sciences 19\% and Faculty of Arts 4\%. The respondents' age ranged between 17 years old and 35 years old (mean age $=27.34$ ). Also, $59 \%$ of respondents studied for bachelor degree, and $16 \%$ reported studying in a group categorized as 'others' that comprised continuing students and all others studying in different levels such as certificate and diploma.

Table 1: Descriptive Analysis

$\%$

\begin{tabular}{ll}
\hline Gender & \\
Male & 41.7 \\
Female & 58.3
\end{tabular}

\begin{tabular}{ll}
\hline Age & \\
$0-25 y e a r s$ & 60.1 \\
$26-35$ & 22.1 \\
36years and above & 17.8 \\
& \\
\hline Faculty & \\
FBSS & 33.2 \\
SCIENCE & 22.1 \\
ENGINEERING & 22.5 \\
FBMS & 18.5 \\
ART & 3.7
\end{tabular}

Source: Survey (2020) 


\subsection{Cronbach's alpha for the study variables}

Cronbach's alpha statistics was prepared to establish the consistency of the variables. According to McKinley, Manku-Scott, Hastings, French, and Baker (1997), for comparing groups, Values of 0.7 to 0.8 on the Cronbach's alpha scale are considered satisfactory. However, lower thresholds are occasionally used in literature. Nunnaly (1978) has stated that 0.5 is a sufficient value, while 0.7 is a more reasonable Cronbach's alpha.

Table 2: Cronbach's alpha values of study variables

\begin{tabular}{|l|l|l|}
\hline Constructs & $\begin{array}{l}\text { Number of } \\
\text { items }\end{array}$ & $\begin{array}{l}\text { Cronbach's } \\
\text { alpha }\end{array}$ \\
\hline Entrepreneurial Activities and Intentions of students & 6 & 0.72 \\
\hline $\begin{array}{l}\text { Entrepreneurial programmes and platforms created by the } \\
\text { school }\end{array}$ & 5 & 0.86 \\
\hline Career choice intentions immediately after graduation & 5 & 0.76 \\
\hline Obstacles to the realization of entrepreneurship & 3 & 0.74 \\
\hline
\end{tabular}

Source: Survey (2020)

The Cronbach's alpha is shown in the table above. Values of the study variables range from $0.7 \mathrm{a}$ to $0.86 \mathrm{a}$; this is an adequate and sufficient research tool for this study.

\subsection{Entrepreneurial Activities and Intentions of students}

Ajzen's (1991) TPB theory's key argument is that the individual's intentions preclude a specific behaviour's performance. Intentions are assumed to be the motivation for a particular behaviour. Thus, the stronger the intention to perform a specific behaviour, the more likely it will be performed. As seen in Table 3 below, most of the respondents, $79 \%$ of students, have Entrepreneurial intention. In contrast, the remaining $20 \%$ of students have no intention, indicating that most students will show entrepreneurial behaviour or become self-employed.

Table 3: Entrepreneurial Intentions

\begin{tabular}{lcccc}
\hline Assertions & No & $\%$ & Yes & $\%$ \\
\hline I have already started a business & 151 & 60.4 & 99 & 39.6 \\
I have formulated a business plan but yet to implement it & 109 & 43.4 & 142 & 56.6 \\
I have identified a market opportunity but yet to explore it & 113 & 45.1 & 137 & 54.9 \\
I have worked on product development & 152 & 60.7 & 98 & 39.3 \\
I have taken steps to identify and discuss with potential customers & 129 & 51.4 & 122 & 48.6 \\
& & & & \\
I have never thought of starting a business & 180 & 72.1 & 70 & 27.9 \\
I have even sought funding from a financial institution & 164 & 65.5 & 86 & 34.5 \\
I will like to start a business after schooling & 51 & 20.5 & 199 & 79.5 \\
\hline
\end{tabular}

Source: Survey (2020) 
The level of entrepreneurial intention and preparedness of the students was descriptively examined. The study found that above $60 \%$ of the students have not started any business or entrepreneurial activities. More than half of the respondents have formulated a business plan but yet to implement it. In comparison, $54 \%$ of them have identified a market opportunity but yet to explore it. This shows thus that having a plan is not the primary concern, but implementing such a business plan is the problem. It equally implies that the respondents are desirous of engaging in entrepreneurial activities but making such a desired reality is the challenge. Thus, there is a disconnect between students desires and reality, which call for a concern to break the gap.

Also, more than $60 \%$ have not worked on a product or line of business before, $51 \%$ of them have not taken any step to identify and discuss with potential customers, $72 \%$ have never thought of starting a business, and $65 \%$ have never sought for funding from a financial institution. On a good note, about $80 \%$ of them will like to start a business after schooling. This is a promising and sound development. It thus implies that after passing through the academic years, the students plan to engage in actual entrepreneurial activities.

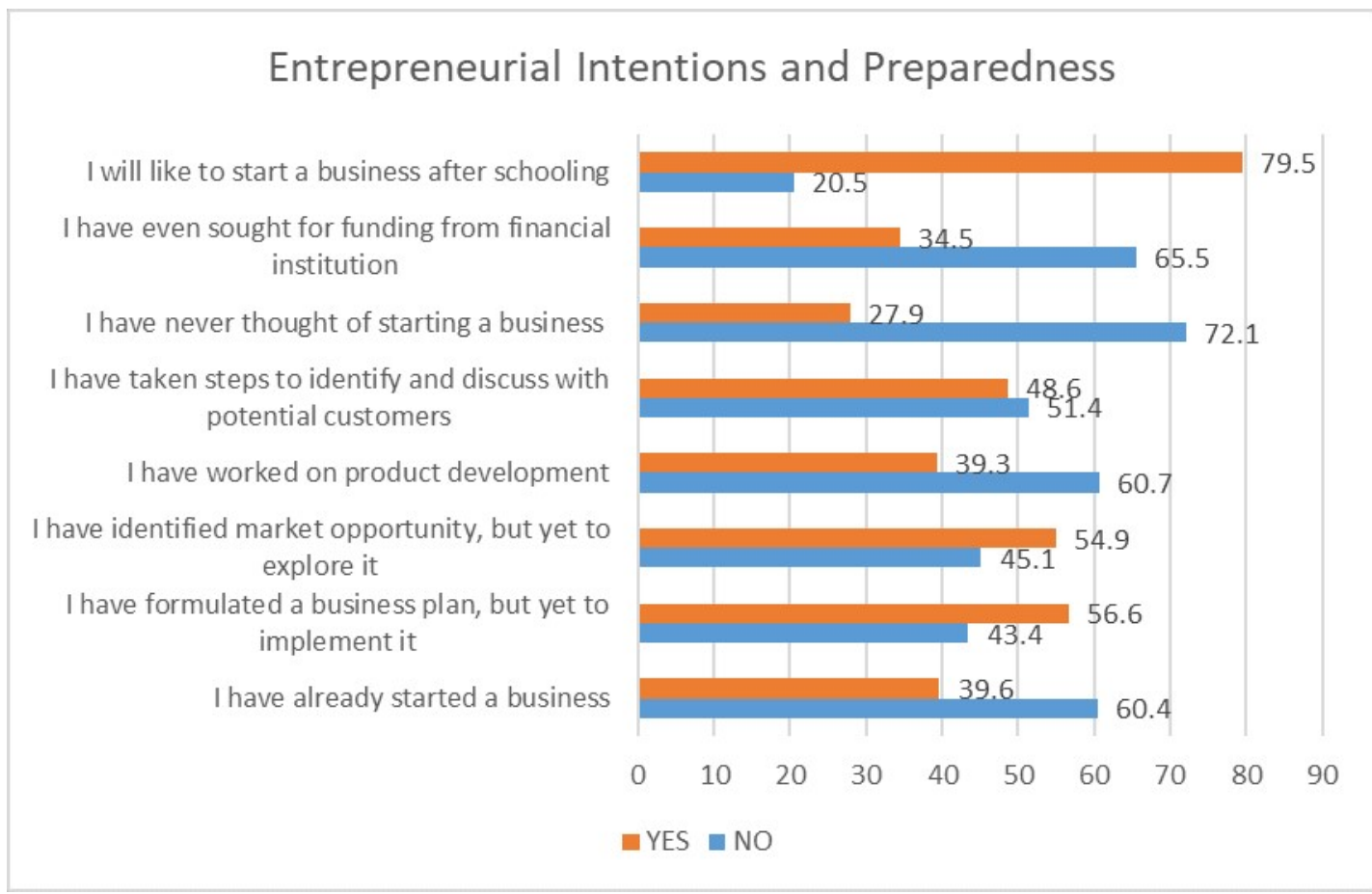

\section{Figure 1: Entrepreneurial Intentions}

Source: Survey (2020)

\subsection{Entrepreneurial Programmes and Platforms}

The school designed the various platforms and activities to stimulate the spirit of entrepreneurship among students in higher institutions, The attendance of the prospective students at these platforms was investigated. Of the sample respondent, $63.4 \%$ have attended contact platform with potential entrepreneurs, $59.7 \%$ have attended business plan contest/workshop. In comparison, $62.9 \%$ of them have participated in the mentoring and coaching programmes for potential entrepreneurs, and only $35 \%$ of them have attended a workshop and network connection with experienced entrepreneurs. 
This shows that the students have substantially participated in the various programmes created for engendering entrepreneurial spirit among the students. Merging these results with the findings on entrepreneurial intention indicated in Table 2 shows that the various programmes' attendance has induced heightened interest in entrepreneurial intention only after school but not in the institution.

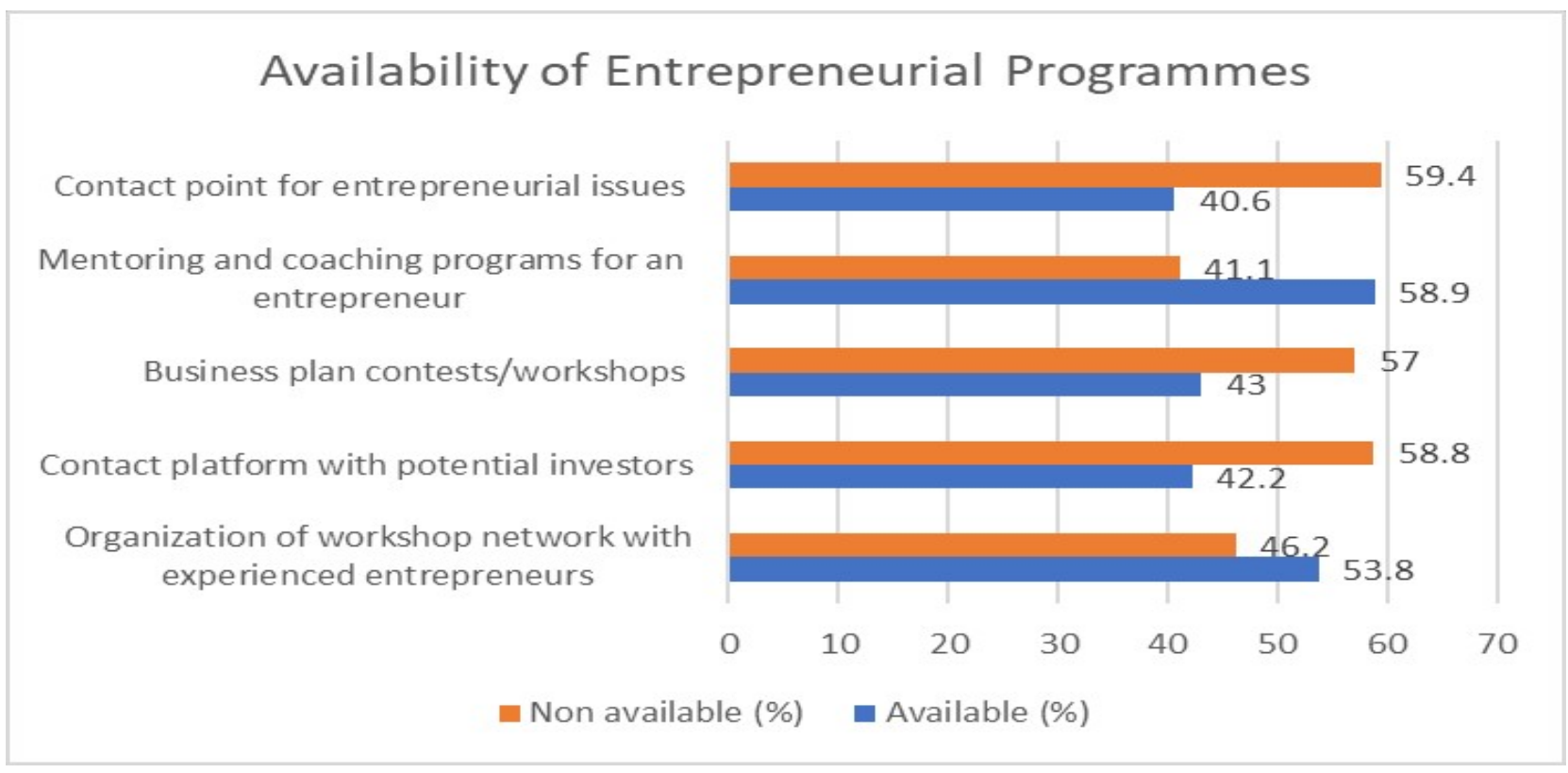

\section{Attendance at Entrepreneurial Programmes}

Contact point for entrepreneurial issues

Mentoring and coaching programs for an entrepreneur

Business plan contests/workshops

Contact platform with potential investors

Organization of workshop network with experienced entrepreneurs

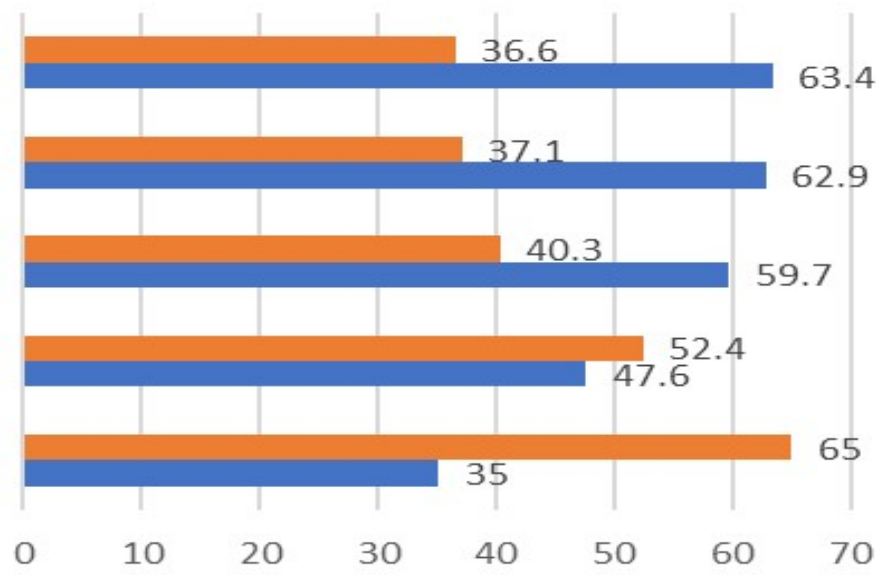

- Attendance No (\%)

- Attendance Yes (\%)

Figure 2: Availability of University Co-Curricular Activities in the School 
Since most of the respondents have shown the willingness to venture into entrepreneurial activities after schooling, this study investigated the career choice intention after graduation.

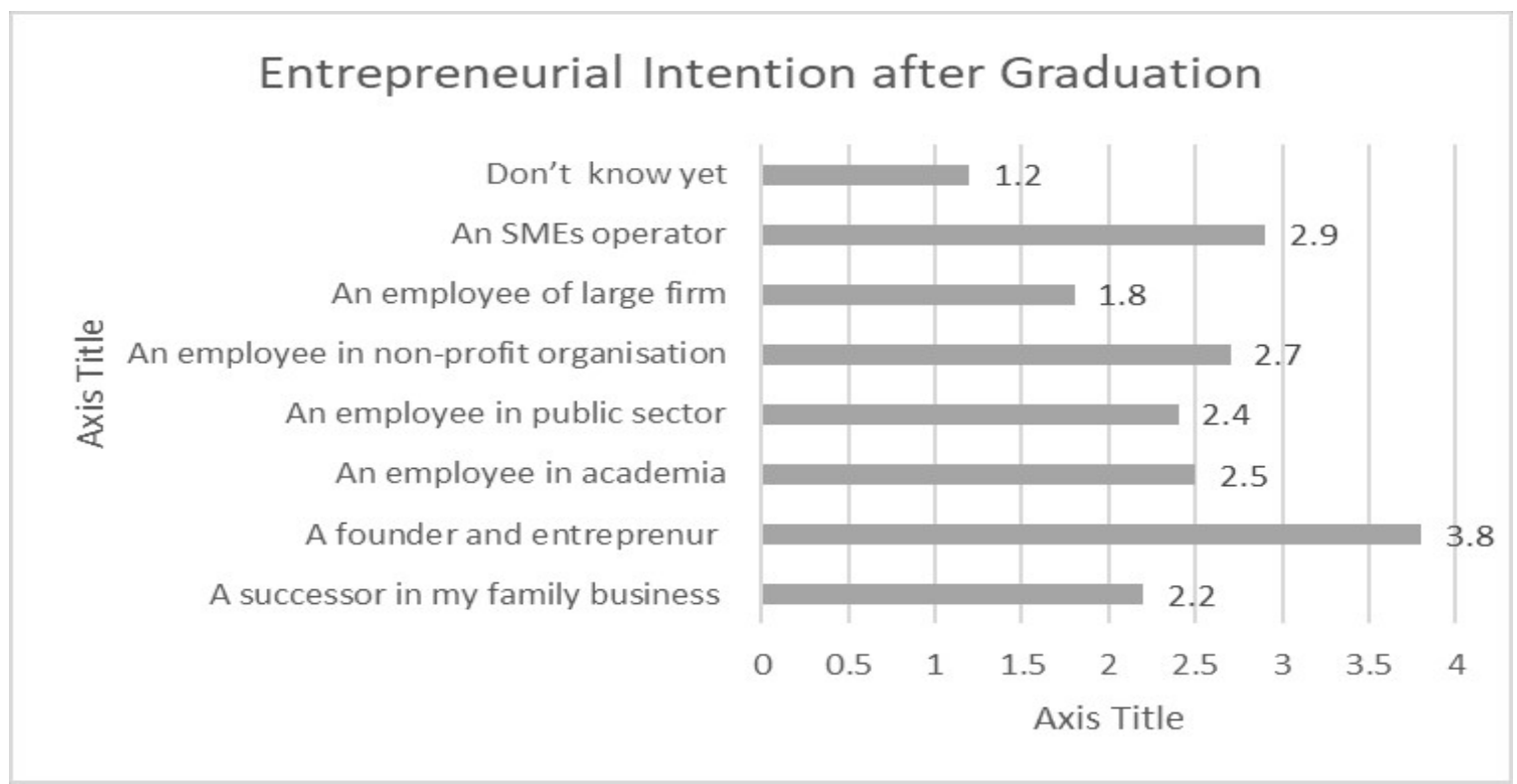

Figure 3: Entrepreneurial Intention after Graduation Source: Survey (2020)

Figure 3 shows that the majority of the respondents with a mean value of 3.8 intend to be an entrepreneur immediately after their graduation, the next was an SME operator with a mean value of 2.9 , followed by being an employee in a non-profit making organization 2.7, and an employee in academia 2.5. Those who do not intend yet recorded the least mean value of 1.2, followed by those willing to work in a large firm 1.8. Therefore, this shows that most of the respondents are ready to be entrepreneurs in the future. Thus, there are potentials in the students which can be tapped and developed. Some obstacles could be emerging because there is a disconnect between the respondents' entrepreneurial motive and fact. The study thus investigated the various barriers that can affect the potential realization of entrepreneurial tendency. Lack of debt capital 3.8, unstable economic policy 3.2, fear of failure 0.8 , technical know-how deficit 3.4, and lack of the right business idea 1.9 were found to be very significant barriers to the realization of entrepreneurship intentions. 


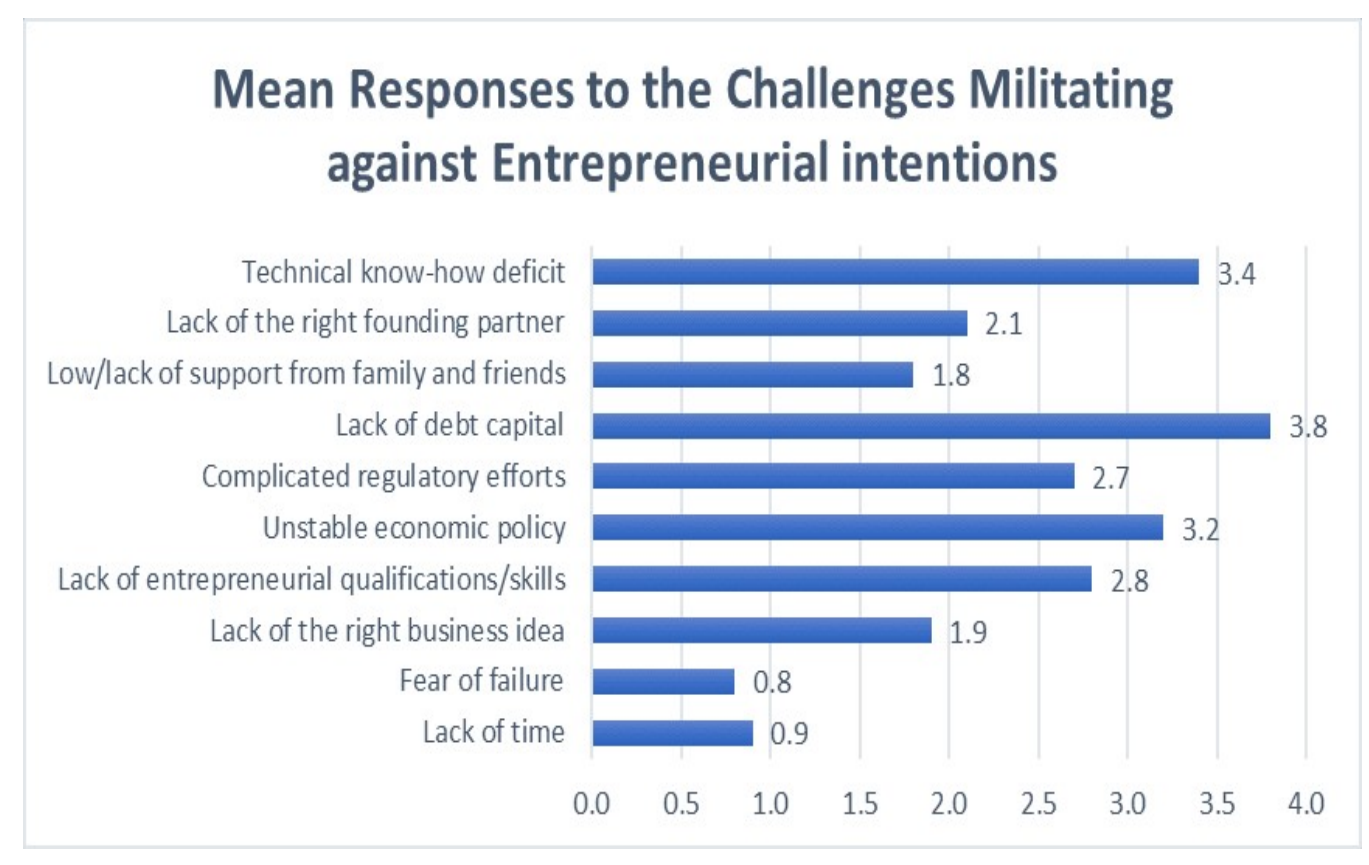

Figure 4: Obstacles for establishing a business

Source: Survey (2020)

\subsection{Correlations}

To determine the relationship between the variables, including gender, age, education, entrepreneurial program, and family, a correlation analysis was performed. The association's strength was measured using the Pearson Product-moment correlation coefficient when the significance level is $p<.01$ and $p<0.05$.

Table 5 shows the association between the variables, revealing a positive and vital relationship $(r=.63)$ between attitude toward behaviour and entrepreneurship purpose. The results do not rule out hypothesis 1: There is a connection between attitude toward behaviour and entrepreneurship purpose. The attitude toward the behaviour related to entrepreneurship increases; it will also increase the intention toward entrepreneurship. Those who have favourable attitudes of being entrepreneurs tend to show a higher intention to be involved in entrepreneurship after graduating.

\section{Table 5: Correlation Analysis}

\begin{tabular}{llllllll}
\hline & Gender & Age & Edu & Disc & Family & Entre_Prog & Ent_Int \\
\hline Gender & 1 & & & & & & \\
Age & $\left..45^{* *}\right)$ & 1 & & & & & \\
Edu & $.36\left(^{* *}\right)$ & $.59\left(^{* *}\right)$ & 1 & & & & \\
Disc & .72 & $.19\left(^{*}\right)$ & $.32\left(^{(* *}\right)$ & 1 & & & \\
Family & $\left..62^{* *}\right)$ & $.38\left(^{*}\right)$ & .61 & .24 & 1 & & \\
Entre_Prog & $.49\left(^{* *}\right)$ & $.38\left(^{* *}\right)$ & $.42\left(^{(* *}\right)$ & .62 & $.21\left(^{* *}\right)$ & 1 & \\
Ent_Int & $\left..63^{* *}\right)$ & $.14\left(^{*}\right)$ & $.39\left(^{(*)}\right.$ & .27 & .61 & $.89\left(^{* *}\right)$ & 1 \\
\hline
\end{tabular}

${ }^{* *}$ At the 0.01 level, correlation is essential (2 tailed).

* At the 0.05 level, the correlation is essential (2-tailed). 


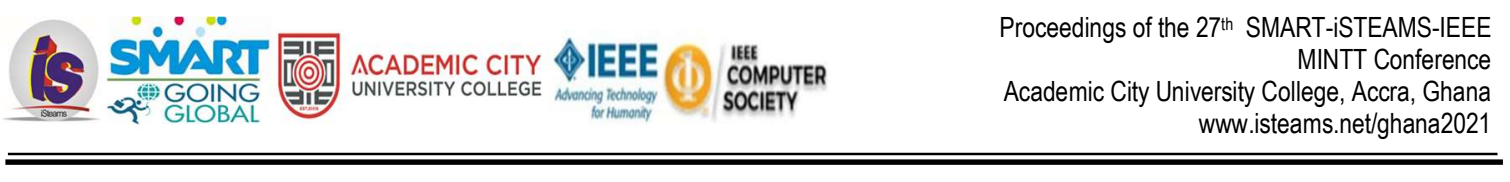

The result shows that family has a positive and significant relationship with entrepreneurial intention ( $r=62)$. The perception of family and friends' approval of their decision to become entrepreneurs increases, so the intention is involved in entrepreneurship after graduation also increases. Also, gender disparity is positively and significantly associated with entrepreneurial intention $(r=0.63)$, and further descriptive analysis shows that males are more inclined towards forming entrepreneurship than their female counterparts. The entrepreneurial programme offered in school was also positively and significantly associated with entrepreneurial intention $(r=$ 0.89). This implies that the school's entrepreneurial programme stimulates the students' interest in entrepreneurship. This equally shows that the entrepreneurial programme is productive and resourceful in promoting entrepreneurial intention among the students. This means that as the incentive to pursue entrepreneurship after graduation increases, so makes sense of control over the growth of a new business. Hypothesis 1 is not supported by this result. This study's results seem to be consistent with the submission in Brush (1992), who argued that females with similar backgrounds are less entrepreneurship-oriented than male counterparts because women have to face many social barriers in developing countries.

These findings support the prior literature claims that entrepreneurship education or programme engenders entrepreneurial intentions (Wilson et al., 2007). Students who participated in entrepreneurship programme have indicated more intentions towards starting their own business (Noel, 1998) because entrepreneurship programme develops a vision among students to create their own business with innovation (Wilson, 2007). A further analysis using a t-test was conducted to establish a significant difference between entrepreneurship programme participants and non-participants students regarding their intentions towards entrepreneurship.

Table 6: Independent Samples test for Participation/Non Participation in Entrepreneurship Education

\begin{tabular}{llll}
\hline Students & N & M & S D \\
\hline Participants & 168 & 3.32 & .54 \\
Non participants & 41 & 2.07 & .63 \\
\hline
\end{tabular}

Table 6 shows that, according to Levene's test, there is a gap in entrepreneurship purpose between participants in entrepreneurship education and non-participants in entrepreneurship education students. The mean score of Entrepreneurship Intention from the Entrepreneurship programme participants sample is 3.32 that is higher than that of the non-participant's student's sample, which is 2.07 .

Table 7: Independent Samples Test;

Variances

$\begin{array}{lllccc} & \mathrm{F} & \text { Sig. } & \mathrm{t} & \mathrm{df} & \text { Sig. (2-tailed) } \\ \text { Entr. Prog. } & 5.14 & .02 & -.2 .45 & 183 & .82 \\ \text { Gender } & 1.63 & .32 & -1.62 & 191 & .07\end{array}$

Table 8 shows an independent sample test showing a difference in entrepreneurship intention between male and female students. The mean score of Ent_Int from the male sample is 3.19, which is higher than that of the female student's sample, 1.9. 
Table 8: Independent samples test for female and male students

\begin{tabular}{llll}
\hline Students & $\mathrm{N}$ & $\mathrm{M}$ & $\mathrm{SD}$ \\
\hline Male & 134 & 3.19 & .32 \\
Non participants & 72 & 1.9 & .54 \\
\hline
\end{tabular}

\section{SUMMARY AND DISCUSSION OF FINDINGS}

The study assessed the students' career choice and entrepreneurial intentions of Adeleke University Ede, Nigeria. It established that many students are willing to pursue entrepreneurship immediately after their graduation, but not while in school. Their motivation for entrepreneurship was stimulated by their entrepreneurial programmes and platforms created to heighten entrepreneurship spirit. This is an indication that the school programmes on entrepreneurship are promising and resourceful. Arising from the findings of this study, the earlier stated hypotheses can be verified. Regarding hypothesis one, the study rejected the null hypothesis. It established that students' socio-cultural characteristics such as family, gender, discipline, and age are positively and significantly correlated with entrepreneurial intentions among their undergraduate students.

Furthermore, the study invalidates hypothesis two, proving that academic characteristics such as discipline have a positive and meaningful relationship with entrepreneurial intent among students. Lastly, the study demonstrates that the involvement of students in entrepreneurship-related co-curricular activities is positively related to entrepreneurship development and the start-up activities of undergraduate students. This study's findings support those of Kassean, Vanevenhoven, Liguori, and Winkel (2015), as well as Tahseen, Ahmed, and Tariq (2012), who found a positive and significant relationship between the entrepreneurial program and students' socio-cultural characteristics as influencing entrepreneurial purpose among Pakistani undergraduate students. It is also in line with lakovleva et al. (2011), who investigated entrepreneurial intentions in developing and developed countries. They exhibited that students from developing countries had stronger entrepreneurial intentions than those from developed countries.

This agrees with Krueger's (1993) conclusion and proposes that learners with their business parents expand exposure to and implicit understanding of entrepreneurship from premature age, impacting their attitude and insight of self-efficacy toward entrepreneurship. Learners who directly practice developing their employment have a more positive attitude toward entrepreneurship and self-efficacy in their skills to do again that behaviour. The subject of subjective norms proposes that learners who are more self-assured in their craft based on practice are less inclined by perceived social means about entrepreneurial career. According to the results, there is a clear connection between entrepreneurial education and entrepreneurial intentions. These findings are supported by previous research (Basu \& Virick, 2008; Davey et al., 2011).

Similarly, Solesvik (2013) discovered that students who took part in entrepreneurial education had higher perceived entrepreneurial motivation than students who did not participate in entrepreneurial education. Therefore, it can be stated that a strong relationship and positive correlation exists between entrepreneurial education and intent towards entrepreneurship. Our findings verify the results of preceding research in terms of the significant association between entrepreneurial inclinations and its background and thus provide further support to applying Ajzen" s theory of planned behaviour to predict and understand entrepreneurial mindset. While the findings for differences by gender among learners shows, the results suggest that female students have a less favourable attitude toward entrepreneurship. 


\section{CONCLUSION AND RECOMMENDATION}

This study assessed the entrepreneurial intentions among undergraduate students. This study confirms many previous results in the literature on students' entrepreneurial ambitions. The study has given further evidence of the entrepreneurial programme's importance and socio-cultural influences on the entrepreneurial mindset. Thus, the study concluded that there is generally an increase in entrepreneurial intention occasioned by the school's socio-cultural factors and entrepreneurial programmes and platforms. An exciting submission in this study is the students' heightened willingness to venture into entrepreneurial activities within the five years of their graduation but unwilling to engage in such activities while still in the school. This study recommends that universities focus their attention on attracting students towards entrepreneurial programmes as students who attended entrepreneurial courses/training showed significantly higher entrepreneurial intentions. The school and parents should equally provide moral and financial encouragement to motivate students into entrepreneurial development. Universities should increase the number of entrepreneurship courses/training and provide students from all faculties/departments with the opportunity to participate in these courses/training.

\section{Limitation}

The finding of this study is based on a small sample size of 268 students. The study was conducted on students, so the results are not generalized to graduates nor postgraduate students. Despite these flaws, the research contributes to the body of knowledge about the antecedents of the entrepreneurial mentality and the variables that influence learners' attitudes, social norms, and perceived behavioural regulation. Future research should study these topics with large sample size. Future research should look into the effect of entrepreneurship education on student leadership growth and digital entrepreneurship.

\section{REFERENCES}

1. Adamu, M. M. (2017). Delivering inclusive growth for economic development in Nigeria. International Journal of Entrepreneurial Development, Education and Science Research, 4(1), 209-217.

2. Adelowo, C. M., Joshua, A., \& Ilevbare, O. E. (2018). Entrepreneurship Potentials among Undergraduates in Nigerian Universities: Empirical Evidence. AMC Indian Journal of Entrepreneurship, 1(2), 36-51.

3. Adelowo, C. M., Edoho, F. M., Ilori, M. O., Siyanbola, W. O., \& Oluwale, B. A. (2015). Technological learning mechanisms in Nigeria's technology incubation centre. African Journal of Economic and Management Studies.

4. Agbim, K. C., Oriarewo, G. O., \& Owocho, M. (2013). Factors influencing entrepreneurial intentions among graduates of Nigerian tertiary institutions. International Journal of business and management invention, 2(4), 36-44.

5. Ajzen, I. Madden, T. J., \& Ellen, P. S. (1992). A comparison of the theory of planned behaviour and the theory of reasoned action. Personality and social psychology bulletin, 18(1), 3-9.

6. Akanbi, S. T. (2013, December). Familial factors, personality traits, and self-efficacy are determinants of entrepreneurial intention among vocational-based college students in Oyo State, Nigeria. In The African Symposium (Vol. 13, No. 2, pp. 66-76).

7. Akram, A. M., Zain, Z. M., \& Ghani, E. K. (2010). Entrepreneurship intention among Malaysian business students. Canadian social science, 6(3), 34-44. 
8. Aluwong, D. S. W. (2010). Entrepreneurial and Functional Business Education as Means of Achieving the National Objectives of Vision 2020 in Nigeria.

9. Autio, E., H. Keeley, R., Klofsten, M., GC Parker, G., \& Hay, M. (2001). Entrepreneurial intent among students in Scandinavia and the USA. Enterprise and Innovation Management Studies, 2(2), 145-160.

10. Bates, T., Bradford, W. D., \& Seamans, R. (2018). Minority entrepreneurship in twenty-first-century America. Small Business Economics, 50(3), 415-427.

11. Bergmann, H., Hundt, C., \& Sternberg, R. (2016). What makes student entrepreneurs? On the relevance (and irrelevance) of the university and the regional context for student start-ups. Small business economics, 47(1), 53-76.

12. Bhandari, N. C. (2013). Relationship Between Students' Grades and School Year and Their Intention for Entrepreneurship: Some Pioneering Findings. New England Journal of Entrepreneurship, 16(1), 6.

13. Boissin, J. P., Branchet, B., Emin, S., \& Herbert, J. I. (2009). Students and entrepreneurship: a comparative study of France and the United States. Journal of Small Business \& Entrepreneurship, 22(2), 101-122.

14. Brush, C. G. (1992). Marketplace information scanning activities of new manufacturing ventures. Journal of Small Business Management, 30(4), 41.

15. Dickson, P. H., Solomon, G., Solomon, G. T., \& Weaver, K. M. (2008). Entrepreneurial selection and success: does education matter?. Journal of small business and enterprise development.

16. Dohse, D., \& Walter, S. G. (2010). The role of entrepreneurship education and regional context in forming entrepreneurial intentions (No. 2010, 18). Document de treball de l'IEB.

17. Ekpe, I., Adubasim, E. I., \& Adim, V. C. (2016). Effect of Price, Advertising and Motivation on Online Purchase Behaviors among Youth Academic Entrepreneurs in Nigeria: Social Influence as Moderator. International Journal of Entrepreneurship, 20, 42.

18. Ekpoh, U. I., \& Edet, A. O. (2011). Entrepreneurship education and career intentions of tertiary education students in Akwa Ibom and Cross River States, Nigeria. International Education Studies, 4(1), 172-178.

19. Fayolle, A., Liñán, F., \& Moriano, J. A. (2014). Beyond entrepreneurial intentions: values and motivations in entrepreneurship. International Entrepreneurship and Management Journal, 10(4), 679689.

20. Fretschner, M., \& Weber, S. (2013). Measuring and understanding the effects of entrepreneurial awareness education. Journal of small business management, 51(3), 410-428.

21. Gasse, Y., \& Tremblay, M. (2011). Entrepreneurial beliefs and intentions: a cross-cultural study of university students in seven countries. International journal of business, 16(4), 303.

22. Gerry, C., Marques, C. S., \& Nogueira, F. (2008). Tracking student entrepreneurial potential: personal attributes and the propensity for business start-ups after graduation in a Portuguese university. Problems and Perspectives in Management, 6(4), 45-53.

23. Gries, T., \& Naudé, W. (2011). Entrepreneurship and human development: A capability approach. Journal of Public Economics, 95(3-4), 216-224.

24. Gurel, E., Altinay, L., \& Daniele, R. (2010). Tourism students' entrepreneurial intentions. Annals of Tourism Research, 37(3), 646-669.

25. Hartung, P. J., Porfeli, E. J., \& Vondracek, F. W. (2005). Child vocational development: A review and reconsideration. Journal of vocational behaviour, 66(3), 385-419.

26. Ismail, M., Khalid, S. A., Othman, M., Jusoff, H. K., Rahman, N. A., Kassim, K. M., \& Zain, R. S. (2009). Entrepreneurial intention among Malaysian undergraduates. International Journal of Business and Management, 4(10), 54-60. 
27. Karimi, S., Biemans, H. J., Lans, T., Chizari, M., \& Mulder, M. (2014). Effects of role models and gender on students' entrepreneurial intentions. European Journal of Training and Development.

28. Keat, O. Y., Selvarajah, C., \& Meyer, D. (2011). Inclination towards entrepreneurship among university students: An empirical study of Malaysian university students. International Journal of Business and Social Science, 2(4)

29. Lima, E., Lopes, R. M., Nassif, V., \& Silva, D. (2015). Opportunities to improve entrepreneurship education: Contributions considering Brazilian challenges. Journal of Small Business Management, 53(4), 1033-1051.

30. Liñán, F., Urbano, D., \& Guerrero, M. (2011). Regional variations in entrepreneurial cognitions: Startup intentions of university students in Spain. Entrepreneurship and Regional Development, 23(3-4), 187-215.

31. Lüthje, C., \& Franke, N. (2003). The making of an entrepreneur: testing a model of entrepreneurial intent among engineering students at MIT. R\&d Management, 33(2), 135-147.

32. Maina, S. (2014). The role of entrepreneurship education on job creation among youths in Nigeria. International Letters of Social and Humanistic Sciences, (04), 87-96.

33. Malebana, M. J. (2014). The effect of knowledge of entrepreneurial support on entrepreneurial intention. Mediterranean Journal of Social Sciences, 5(20), 1020-1020.

34. Muofhe, N. J. \& Du Toit, W. F. (2011). Entrepreneurial education's and entrepreneurial role models' influence on career choice. SA Journal of Human Resource Management, 9(1), 1-15.

35. Nafukho, F., Nafukho, F. M., \& Muyia, M. A. H. (2010). Entrepreneurship and socio-economic development in Africa: reality or myth?. Journal of European Industrial Training.

36. Noel, T. W. (2002). Effects of entrepreneurial education on intent to open a business: An exploratory study. Journal of Entrepreneurship Education, 5, 3.

37. Ntemngweh, P. (2016). Education-job mismatch among university graduates in Cameroon: The perspectives of graduates in humanities (Master's thesis).

38. Olofinyehun, A. O., Adelowo, C. M., \& Egbetokun, A. A. (2018). The supply of high-quality entrepreneurs in developing countries: evidence from Nigeria. Science and Public Policy, 45(2), 269282.

39. Owoseni, O. O. (2014). The influence of some personality factors on entrepreneurial intentions. International Journal of Business and Social Science, 5(1).

40. Sandhu, M. S., Sidique, S. F., \& Riaz, S. (2011). Entrepreneurship barriers and entrepreneurial inclination among Malaysian postgraduate students. International journal of entrepreneurial behaviour \& research.

41. Schröder, E., Schmitt-Rodermund, E., \& Arnaud, N. (2011). Career choice intentions of adolescents with a family business background. Family Business Review, 24(4), 305-321.

42. Schwarz, E. J., Wdowiak, M. A., Almer-Jarz, D. A., \& Breitenecker, R. J. (2009). The effects of attitudes and perceived environment conditions on students' entrepreneurial intent. Education+ Training.

43. Shariff, M. N. M., \& Saud, M. B. (2009). An attitude approach to the prediction of entrepreneurship on students at an institution of higher learning in Malaysia. International Journal of Business and Management, 4(4), 129-135.

44. Sieger, P., \& Monsen, E. (2015) Founder; Academic, or Employee? A Nuanced Study of Career Choice Intentions, Journal of Small Business Management. 53(S1), 30-57. 
45. Siyanbola, W. O., Afolabi, O. O., Jesuleye, O. A., Egbetokun, A. A., Dada, A. D., Aderemi, H. O., ... \& Rasaq, M. A. (2012). Determinants of the entrepreneurial propensity of Nigerian undergraduates: an empirical assessment. International Journal of Business Environment, 5(1), 1-29.

46. Temtime, Z. T., Chinyoka, S. V., \& Shunda, J. P. W. (2004). A decision tree approach for integrating small business assistance schemes. Journal of Management Development.

47. Turker, D., \& Selcuk, S. S. (2009). Which factors affect the entrepreneurial intention of university students?. Journal of European industrial training.

48. Thompson, P., Jones-Evans, D., \& Kwong, C. (2009). Women and home-based entrepreneurship: Evidence from the United Kingdom. International Small Business Journal, 27(2), 227-239.

49. Urbano, David, Sebastian Aparicio, and David Audretsch. "Twenty-five years of research on institutions, entrepreneurship, and economic growth: what has been learned?." Small Business Economics 53.1 (2019): 21-49.

50. Urbano, D., Aparicio, S., Guerrero, M., Noguera, M., \& Torrent-Sellens, J. (2017). Institutional determinants of student employer entrepreneurs at Catalan universities. Technological Forecasting and Social Change, 123, 271-282.

51. Wang, C. K., \& Wong, P. K. (2004). The entrepreneurial interest of university students in Singapore. Technovation, 24(2), 163-172.

52. Wickham, P. A. (2006). Strategic entrepreneurship. Pearson Education.

53. Wilson, C., \& Dowlatabadi, H. (2007). Models of decision making and residential energy use. Annual review of environment and resources, 32.

54. Zellweger, T., Sieger, P., \& Halter, F. (2011). Should I stay or should I go? Career choice intentions of students with a family business background. Journal of business venturing, 26(5), 521-536. 